\title{
Erratum to: Pancreatic $\beta$-cell regeneration: advances in understanding the genes and signaling pathways involved
}

Solomon Afelik ${ }^{1 *}$ and Meritxell Rovira ${ }^{2^{*}}$

\section{Erratum}

Following the publication of of this article [1], it was brought to our attention that unfortunately an error was introduced during copyediting:

Due to the error, the heading of the article's second main section incorrectly reads: " $\beta$ cell regeneration from pancreatic acinar, ductal or $\beta$ cell lineages requires $N g n 3$ activation".

The correct heading should instead read: " $\beta$ cell regeneration from pancreatic acinar, ductal or $\alpha$ cell lineages requires Ngn3 activation".

Received: 1 June 2017 Accepted: 1 June 2017

Published online: 06 June 2017

\section{Reference}

1. Afelik and Rovira: Pancreatic $\beta$-cell regeneration: advances in understanding the genes and signaling pathways involved. Genome Medicine (2017) 9:42. DOI 10.1186/s13073-017-0437-x

\footnotetext{
*Correspondence: safelik@uic.edu; mrovira@cmrb.eu

'Division of Transplantation, Department of Surgery, University of Illinois at Chicago, 840 South Wood Street, CSB 920 (Rm 502), Chicago, IL 60612, USA ${ }^{2}$ Center of Regenerative Medicine in Barcelona (CMRB), Dr. Aiguader 88, 08003 Barcelona, Spain
} 